\title{
Determination of the Microflora of Meatless Cig Kofte in the Black Sea Region of Turkey
}

\author{
Duygu Balpetek Külcü ${ }^{1}$, Sena Soğuksulu ${ }^{1}$, Yunus Çakan ${ }^{1}$, Çağla Ergen ${ }^{1}$ \\ ${ }^{1} 1$ Giresun University, Faculty of Engineering, Department of Food Engineering, Giresun, Turkey
}

Received: 23 March 2020, Accepted: 14 May 2020, Published online: 31 August 2020

(C) Ordu University Institute of Health Sciences, Turkey, 2020

\begin{abstract}
Objective Meatless Cig Kofte (MCK) is a traditional product consumed frequently in Turkey. In recent years, MCK shops have been opened and offered to the public. It is important for public health because it is a risky food for microbial contamination. This study was conducted to investigate some microbiological quality of MCK sold in Black Sea region (Trabzon, Giresun, Ordu, Samsun) in Turkey.

Methods: In this study, a total of 120 MCK were sampled from different points of sales and examined for the microbiological quality of MCK in the Black Sea Region (Trabzon, Giresun, Ordu and Samsun). Data analysis of the study was conducted using SPSS 24 package program. Statistical significance was evaluated at $\mathrm{p}<0.05$.

Results: According to the research results, the highest average TMAB (Total Mesophilic Aerobic Bacteria) value of MCK samples was determined in Giresun province (6.04 log cfu/g) and the lowest average value was found in Samsun province. While the average TPAB (Total Psychophilic Aerobic Bacteria) was determined as $1.82 \mathrm{log} \mathrm{cfu} / \mathrm{g}$ in MCK samples collected from Samsun province, it could not be detected in Trabzon, Ordu and Giresun provinces. The average S. aureus value of MCK samples was determined in the highest province of Ordu (4.22 log cfu/g) and the lowest in Trabzon province (1.94 log cfu/g).

Conclusion: It was concluded that microbial quality was insufficient and hygiene rules were not taken into consideration in the provinces that were included in this study conducted in the Black Sea Region (TrabzonGiresun-Ordu-Samsun).
\end{abstract}

Key words: Black Sea Region; meatless cig kofte; microbial quality; public health

Suggested Citation: Balpetek Kulcu D, Soguksulu S, Cakan Y, Ergen C. Determination of the Microflora of Meatless Cig Kofte in the Black Sea Region of Turkey. Middle Black Sea Journal of Health Science, 2020; 6(2):129-134.

\section{Address for correspondence/reprints:}

Duygu Balpetek Külcü

Telephone number: +90 (543) 3101740

ORCID-ID 0000-0002-3300-3342

E-mail: duygu.balpetek@giresun.edu.tr

DOI: $10.19127 / \mathrm{mbsjohs.707934}$

\section{Introduction}

MCK may include bulgur, red pepper, onion, garlic, various spices, tomato paste, tomato sauce, pepper paste, sugar, vinegar, pomegranate syrup, walnut, almond, hazelnut, water and some or all vegetable oils. In addition, when the necessary additives in accordance with the legislation are mixed and kneaded by hand or by machine until it reaches a certain consistency, it becomes ready for consumption without any heat treatment or freezing (TSE, 2018).

MCK, which is one of the ready-to-eat foods, is consumed without heat treatment. Inadequate 
personnel hygiene during production, contamination from the tools and equipment, and the additives in the composition of MCK, can cause food poisoning (Ardıç and Durmaz, 2008).

Microbial analyses are performed to determine the quality of food products in terms of public health. There is a risk of spoilage occurrence during storage since no heat treatment and microbial inhibition treatment is applied to ready-to-eat foods until the time to sale (Delikanlı et al., 2014). Species of vegetable origin may include fertilizer, water, soil and the loads of animal-borne microorganisms. It is possible that microorganisms can get contaminated because of the spices used in the production of MCK.

The aim of this study is to investigate the MCK which is offered for sale in the Black Sea Region (Trabzon-Giresun-Ordu-Samsun) in terms of microbial quality. The reliability of MCK, which are liked and consumed by consumers, has been investigated in terms of public health.

\section{Methods}

\section{Sample collection}

In this study, a total of 120 MCK samples (30 grams from each city) were collected from different point of sales in the Black Sea Region (Trabzon, Giresun, Ordu and Samsun) between October, 2018 and January, 2019, and each sample was 200 grams. All MCK samples were carried in a mini cooler and brought to the Giresun University laboratory, and the analyses were initiated within an hour after sample collection (figure 1).

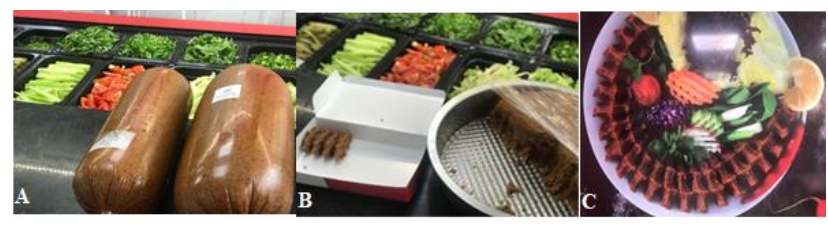

A. MCK Samples in block form B. Packaged MCK samples C. MCK Samples

Fig. 1. Samples of MCK, which is a traditional product sold at different points of sales. A. The Block MCK samples in chilled or frozen form. B. MCK samples in packaged form C. Ready-to-eat MCK samples

\section{Determination of $p H$}

The $\mathrm{pH}$ values of the MCKs were determined by using a digital $\mathrm{pH}$ meter (OHAUS, Starter 3000, Germany).

\section{Microbiological analyses}

The MCK samples, each of which weighed 10 grams, were brought to the laboratory under aseptic conditions and homogenized with $90 \mathrm{~mL}$ Maximum
Recovery Diluent (MRD, Merck, Germany). Dilution of the solution obtained from $10^{-} 1$ dilution up to $10^{-} 6$ was made. The selective agar was inoculated with 0.1 $\mathrm{mL}$ of 2 parallels 3 replicas of each dilution. The inoculated petri dishes were incubated under appropriate conditions. The most probable number (MPN) method was used for the detection of E. coli and coliform microorganisms (Table 1) (Halkman, 2005; Andrews, 1992).

\section{Statistical analysis}

Data were analyzed using One way ANOVA and Duncan's post hoc tests by using IBM SPSS 24 software (SPSS Inc., Chicago, IL, USA) with a significance level of 5\% (Table 1).

\begin{tabular}{llcl}
\hline Microorganism & \multicolumn{1}{c}{ Medium } & \multicolumn{2}{c}{$\begin{array}{c}\text { Incubation } \\
\text { conditions }\end{array}$} \\
\cline { 3 - 4 } TMAB & Plate Count Agar (PCA) & $37^{\circ} \mathrm{C}$ & $24-48 \mathrm{~h}$ \\
\hline $\begin{array}{l}\text { Yeast and } \\
\text { Mold }\end{array}$ & $\begin{array}{l}\text { Potato Dextrose Agar } \\
\text { (PDA) }\end{array}$ & $25-28^{\circ} \mathrm{C}$ & $4-5$ days \\
\hline S. aureus & Baird Parker Agar (BPA) & $37^{\circ} \mathrm{C}$ & $24 \mathrm{~h}$ \\
\hline TPAB & Plate Count Agar (PCA) & $4,5^{\circ} \mathrm{C}$ & 14 days \\
\hline $\begin{array}{l}\text { Coliform } \\
\text { Microorganism }\end{array}$ & Laurly Sulfate Tryptose & $30^{\circ} \mathrm{C}$ & $24 \mathrm{~h}$ \\
\hline E. coli & Laurly Sulfate Tryptose & $37^{\circ} \mathrm{C}$ & $24 \mathrm{~h}$ \\
\hline
\end{tabular}

\section{Results}

As a result of TMAB analysis, significant differences were found in the MCK samples obtained from Trabzon and Giresun provinces. While the samples from Trabzon province gave the lowest value with an average value of 4.66, the samples obtained from Giresun province gave the highest value with an average of 5.44 (Table, 2).

As a result of TPAB analysis, significant differences were found in the MCK samples obtained from Trabzon and Samsun provinces. While the samples from Trabzon province had the lowest value with an average value of 0.65 , the samples obtained from Samsun province had the highest value with an average of 2.74 (Table, 2).

As a result of $S$. aureus analysis, there was no significant difference between the MCK samples obtained from Giresun, Ordu and Samsun. While the MCK samples from Trabzon province had the lowest value with an average value of 2.24 , the samples obtained from Samsun province had the highest value with an average of 3.72 (Table, 2).

According to yeast and mold analysis results, no statistically significant difference was observed in the samples obtained from 4 provinces. While the MCK 


\section{Determination of the Microflora of Meatless Cig Kofte}

samples from Trabzon province had the lowest value with an average value of 3.37, the samples obtained from Samsun province had the highest value with an average of 4.52 (Table, 2).

As a result of coliform analysis, significant differences were found in the MCK samples obtained from Trabzon and Ordu provinces. The lowest value in the MCK samples was found in Trabzon province with an average of 2.09 and the highest value was found in the MCK samples obtained from Ordu province with 40.66 (Table, 2).

According to E. coli analysis, significant differences were found in the samples obtained from Trabzon and Ordu provinces. The lowest $E$. coli value was found in the MCK samples from Trabzon with an average of 1.25 and the highest value was found in the MCK samples obtained from Ordu province with 38.90 (Table, 2).

Table 2. TMAB, TPAB, S. aureus and yeast-mold analysis results of the MCK samples statistical analysis results table

\begin{tabular}{|c|c|c|c|c|}
\hline Analysis & TRABZON & GIRESUN & ORDU & SAMSUN \\
\hline $\begin{array}{l}\text { Total Mesophilic Aerobic Bacteria } \\
\text { (log cfu/gr) }\end{array}$ & $4.66 \pm 1.48^{a}$ & $5.44 \pm 0.81^{\mathrm{b}}$ & $5.25 \pm 1.21^{\mathrm{ab}}$ & $5.18 \pm 0.46^{\mathrm{ab}}$ \\
\hline $\begin{array}{c}\text { Total Psychophilic aerobic Bacteria } \\
\text { (log cfu/gr) }\end{array}$ & $0.65 \pm 1.70^{\mathrm{a}}$ & $1.83 \pm 2.71^{\mathrm{ab}}$ & $1.94 \pm 2.20^{\mathrm{ab}}$ & $2.74 \pm 2.34^{\mathrm{b}}$ \\
\hline $\begin{array}{c}\text { S. aureus } \\
(\log \mathrm{cfu} / \mathrm{gr})\end{array}$ & $2.24 \pm 2.01^{\mathrm{a}}$ & $3.42 \pm 1.40^{\mathrm{b}}$ & $3.52 \pm 1.22^{\mathrm{b}}$ & $3.72 \pm 1.08^{b}$ \\
\hline $\begin{array}{l}\text { Yeast and Mold } \\
\quad(\log \mathrm{cfu} / \mathrm{gr})\end{array}$ & $3.37 \pm 2.15^{\mathrm{a}}$ & $3.51 \pm 2.48^{\mathrm{a}}$ & $4.13 \pm 2.15^{\mathrm{a}}$ & $4.52 \pm 1.36^{\mathrm{a}}$ \\
\hline Coliform (MPN/gr) & $4.57 \pm 2.09^{\mathrm{a}}$ & $25.63 \pm 41.34^{\mathrm{ab}}$ & $40.66 \pm 51.10^{\mathrm{b}}$ & $26.23 \pm 43.68^{\mathrm{ab}}$ \\
\hline E. coli (MPN/gr) & $1.25 \pm 3.16^{\mathrm{a}}$ & $24.4 \pm 41.39^{\mathrm{ab}}$ & $38.90 \pm 51.46^{\mathrm{b}}$ & $25.11 \pm 41.42^{\mathrm{ab}}$ \\
\hline
\end{tabular}

Different letters of mean and standard deviation values in the same line show statistically significant differences between the groups. $(\mathrm{p}<0.05)$

Table 3. Maximum and minimum $\mathrm{pH}$ values of MCK samples

$\begin{array}{cll} & \text { Min Value } & \text { Max Value } \\ \text { TRABZON } & 3.50 & 4.20 \\ \text { GIRESUN } & 3.89 & 4.35 \\ \text { ORDU } & 4.70 & 5.10 \\ \text { SAMSUN } & 3.51 & 5.15\end{array}$

Table 4. The number of TMAB, TPAB, S. aureus and Yeast-Mold findings of MCK samples sold in Trabzon, Giresun, Ordu and Samsun provinces in the Black Sea Region

\begin{tabular}{|c|c|c|c|c|c|}
\hline & & TMAB (log cfu/gr) & TPAB (log cfu/gr) & $\begin{array}{c}\text { S. aureus } \\
(\log \mathrm{cfu} / \mathrm{gr})\end{array}$ & $\begin{array}{l}\text { Yeast and Mold } \\
(\log \mathrm{cfu} / \mathrm{gr})\end{array}$ \\
\hline \multirow{3}{*}{ TRABZON } & Minimum Value & $\mathrm{ND}$ & ND & ND & $\mathrm{ND}$ \\
\hline & Maximum Value & 5.98 & 5.51 & 4.77 & 5.63 \\
\hline & Average Value & 5.46 & ND & 1.94 & 4.57 \\
\hline \multirow{3}{*}{ GIRESUN } & Minimum Value & 4.35 & ND & ND & ND \\
\hline & Maximum Value & 7.84 & 6.61 & 4.43 & 7.58 \\
\hline & Average Value & 6.04 & $\mathrm{ND}$ & 2.07 & 2.54 \\
\hline \multirow{3}{*}{ ORDU } & Minimum Value & ND & ND & ND & ND \\
\hline & Maximum Value & 7.38 & 6.13 & 4.46 & 6.59 \\
\hline & Average Value & 5.81 & ND & 4.22 & 4.98 \\
\hline \multirow{3}{*}{ SAMSUN } & Minimum Value & 3.71 & ND & ND & ND \\
\hline & Maximum Value & 5.98 & 5.55 & 5.38 & 5.85 \\
\hline & Average Value & 5.15 & 1.82 & 3.96 & 5.03 \\
\hline
\end{tabular}

* ND: not Detected 
Table 5. The number of Coliform and E. coli analysis results of the MCK samples obtained from Trabzon, Giresun, Ordu and Samsun in the Black Sea Region

\begin{tabular}{cccc}
\hline & & \multicolumn{2}{c}{ Microorganism } \\
\hline \multirow{3}{*}{ TRABZON } & Minimum Value & E. coli (MPN/g) & Coliform (MPN/g) \\
& Maximum Value & ND & ND \\
& Average Value & 15 & 4.3 \\
GIRESUN & Minimum Value & 1.25 & 2.09 \\
& Maximum Value & ND & ND \\
& Average Value & 110 & 110 \\
ORDU & Minimum Value & 24.40 & 25.63 \\
& Maximum Value & ND & ND \\
& Average Value & 110 & 110 \\
\hline \multirow{3}{*}{ SAMSUN } & Minimum Value & 38.90 & 40.66 \\
& Maximum Value & ND & ND \\
& Average Value & 110 & 110 \\
\hline
\end{tabular}

* ND: not Detected

\section{Discussion}

The aim of this study is to examine the microbiological quality of MCK offered for sale in different provinces of the Black Sea region (Samsun, Ordu, Giresun and Trabzon) and to make an assessment in terms of Public Health. The results of 120 MCK samples collected for this purpose are presented in tables. The results of microbial analysis of 120 MCK samples are given in Tables.

It has been determined that the most important factor in S. aureus transmission to food in cases of food-borne intoxications is human (Akpınar et al., 2019).

S.aureus can be found in raw and processed foods, meat and meat products, salads, skin and nasal mucosa of healthy human (Erol, 2007). The presence of $\mathrm{S}$. aureus in foods is due to the poor hygienic practices of the staff, cross contamination during preparation or improper storage (Pamuk et al., 2013). These bacteria can cause meningitis, septicemia, inflamed wounds and joint rheumatism in humans (Akpınar et al., 2019). High risk conditions during food preparation should be well explained to working personnel (Pamuk et al., 2013).

The number of S. aureus in MCK samples from Trabzon, Giresun, Ordu and Samsun provinces was determined as follows: $1.94 \mathrm{log} \mathrm{cfu} / \mathrm{gr}, 2.07 \mathrm{log}$ $\mathrm{cfu} / \mathrm{gr}, 4.22 \mathrm{log} \mathrm{cfu} / \mathrm{gr}, 3.96 \mathrm{log} \mathrm{cfu} / \mathrm{gr}$ (as mean values). It can be stated that $\mathrm{S}$. aureus values of the MCK samples collected from Trabzon and Giresun provinces are low, and S. aureus values of the MCK samples collected from Ordu and Samsun provinces are high when compared to the average $\mathrm{S}$. aureus results $(5.03 \times 103 \log \mathrm{cfu} / \mathrm{g})$ of the research on the
MCK samples collected from Diyarbakır province by Vural and Yeşilmen (2003).

The temperature range for the development of $\mathrm{S}$. aureus' is $6.7-47.8^{\circ} \mathrm{C}$ and the optimum is $35-37^{\circ} \mathrm{C}$. S. aureus can be easily eliminated during pasteurization or cooking. Also, the optimal $\mathrm{pH}$ range for the development of $\mathrm{S}$. aureus is 6.0-7.1, and most of the strains can reproduce at $\mathrm{pH}$ values between 4.4-10 (Erol, 2007).

The minimum and maximum $\mathrm{pH}$ values of Trabzon, Giresun, Ordu and Samsun provinces were as follows; 3.50-4.20, 3.89-4.35, 4.70-5.10 and 3.515.15 (Table 3). In a study by Kurt et al. (2019), the pH of MCK was found out to be in the range of 3.99-4.84. Compared to the minimum $\mathrm{pH}$ value (3.99) found by Kurt et al. (2019), it was found that the MCK samples collected from Trabzon, Giresun and Samsun provinces have lower $\mathrm{pH}$ values, and the MCK samples from Ordu province have higher $\mathrm{pH}$ values. When compared to the $\mathrm{pH}$ values of this present study, it can be stated that the maximum $\mathrm{pH}$ values (4.84) found in the MCK samples by the same researchers are higher than the samples collected from Trabzon and Giresun provinces, and Ordu and Samsun samples have higher $\mathrm{pH}$ values.

In a study where Cerit et al. (2014) analyzed MCK obtained from Sakarya province, the $\mathrm{pH}$ value was found in the range of 4.8-5.2. When compared with the results of their study, it can be stated that the minimum (4.8) and maximum (5.2) values were higher than the $\mathrm{pH}$ values of the samples collected from all the provinces examined in this research.

The $\mathrm{pH}$ values of the research results are within the range of the $\mathrm{pH}$ value (3.5-5.5) given for the 
Tartar a la turca (Meatless) at the Turkish Standards Institute (TSE, 2018).

Determination of TMAB and yeast-mold presence in foods reveals the microbial quality of food (Delikanli, 2014). These analyzes are indicative of whether the points of food sales obey the hygiene and sanitation rules. The average value of TMAB in MCK samples was determined as $5.46 \mathrm{log} \mathrm{cfu} / \mathrm{g}, 6.04 \mathrm{log}$ $\mathrm{cfu} / \mathrm{g}, 5.81 \mathrm{log} \mathrm{cfu} / \mathrm{g}, 5.15 \mathrm{log} \mathrm{cfu} / \mathrm{g}$ in Trabzon, Giresun, Ordu and Samsun provinces, respectively (Table 4).

The mean value of TMAB in MCK samples was determined as folows: Trabzon; $5.46 \mathrm{log} \mathrm{cfu} / \mathrm{g}$, Giresun; $6.04 \log \mathrm{cfu} / \mathrm{g}$, Ordu; $5.81 \mathrm{log} \mathrm{cfu} / \mathrm{g}$, Samsun; $5.14 \mathrm{log}$ cfu/g in Trabzon, Giresun, Ordu and Samsun provinces respectively (Table 4).

The average TMAB values of the study were found out to be lower when compared to the study conducted by Kardeş (2017) (average $7.86 \log \mathrm{cfu} / \mathrm{g}$ ). It can be stated that the average TMAB values of samples obtained from Trabzon, Giresun and Ordu provinces are high when compared to the findings (1.6x105 cfu/g) of the study by Cerit et al. (2014), while the average values of the samples obtained from Samsun province are low.

The average TPAB values of the study were found out to be lower when compared to the study conducted by Aslan et al. (2012) (average $4.54 \mathrm{log}$ $\mathrm{cfu} / \mathrm{g}$ ).

The average number of yeast and mold in MCK samples from Trabzon, Giresun, Ordu and Samsun provinces are as follows respectfully; $4.57 \mathrm{log} \mathrm{cfu} / \mathrm{g}$, $2.54 \mathrm{log} \mathrm{cfu} / \mathrm{g}, 4.98 \mathrm{log} \mathrm{cfu} / \mathrm{g}, 5.03 \mathrm{log} \mathrm{cfu} / \mathrm{g}$. The results of this study (on average) were found to be lower when compared to the results $(7.44 \log \mathrm{cfu} / \mathrm{g})$ of the study of MCK obtained from Siirt province by Kardeş (2017). The yeast mold average values of MCK samples collected from all provinces studied in this research were found to be low compared to the values $(7.44 \log \mathrm{cfu} / \mathrm{g})$ of the study done by Kardeş (2017) on MCK samples obtained from Siirt province. When the findings of this study are compared with the average yeast-mold results (3.32 $\log \mathrm{cfu} / \mathrm{g}$ ) of the study on MCK samples by Cerit et al. (2014), the average values of the samples collected from Giresun province are lower compared to their research findings and the average values of the samples collected from Trabzon, Ordu and Samsun provinces are higher. When the findings of this study are compared in terms of the number of yeast-mold with the research on MCK offered for the consumption in the center of Bursa the results (2.9x104 cfu/g) found by Delikanli et al. (2014) are lower than the average value obtained from the samples collected from Trabzon, Ordu and Samsun provinces, while they are higher than the samples collected from Giresun province.

When compared to the results $(2.9 \times 104 \mathrm{cfu} / \mathrm{g}$ (4.46 log cfu/g) of the study on MCK samples obtained from the center of Bursa by Delikanli et al. (2014), in terms of the number of yeast-mold, the average value of samples collected from Trabzon, Ordu and Samsun provinces is high and the average value of samples collected from Giresun province is low. The most important group in Food Microbiology is coliform microorganisms and they are evaluated as the indicators of hygiene in foods. For some foods, they are intended to 'disappear' in a certain amount of samples, while in many foods, plant and soil origin coliforms are allowed to be present in certain numbers. For this purpose, counting or presenceabsence tests are applied in coliform group analyses (Akpinar et al., 2019).

Average coliform microorganisms in MCK samples collected from Trabzon, Giresun, Ordu and Samsun provinces are 2.09 MPN/g, 25.63 MPN/g, $40.66 \mathrm{MPN} / \mathrm{g}, 26.23 \mathrm{MPN} / \mathrm{g}$ respectively. When compared to the results of this present study, the average coliform microorganism value (3.7x101 MPN/g) of the MCK samples obtained from Sakarya province by Cerit et al. (2014) is higher than Trabzon, Giresun and Samsun provinces and lower than Ordu province.

Coliform group bacteria are considered as a hygiene indicator in foods (Akpinar et al., 2019). Non-pathogenic strains of E. coli, one of the coliform group members, are found in the normal intestinal flora of all humans and generally all those that are warm-blooded (Erol, 2007). The presence of E. coli in samples of food, environment etc. indicates direct fecal contamination. E. coli can often be found in many foods due to poor hygienic conditions (Akpınar et al., 2019).

The findings of this study on the determination of average E. coli count are as follows: $1.25 \mathrm{MPN} / \mathrm{g}$, $24.40 \mathrm{MPN} / \mathrm{g}, \quad 38.90 \mathrm{MPN} / \mathrm{g}, \quad 25.11 \mathrm{MPN} / \mathrm{g}$ respectively for Trabzon, Giresun, Ordu and Samsun provinces. When compared with the average values of this study, the average E. coli value (1.6x101 MPN/g) of the study by Cerit et al. (2014) is lower than Giresun, Ordu and Samsun provinces and higher than Trabzon provinces.

In the literature search, microbiological, serological and histological studies were mostly used on the meatballs (including raw meat), and different parameters were used. 


\section{Conclusion}

As a result, MCK, as a food product ready for consumption is traditionally consumed in Turkey. Since the materials of the MCK are not heat treated and the preparation stage is manual, they can create food safety problems for the consumer under unhygienic production conditions. In addition, depending on the production and storage conditions, the first hygienic quality of raw materials is important for microbial development. In MCK which is sold by retail, production can be made under conditions that do not comply with hygiene and sanitation rules, and the product may be spoiled because of storing it under inappropriate temperature conditions. Many indicator and pathogen microorganisms can be found and develop in the composition of MCK, which is dangerous for human health. In this study, microbial quality of MCK ready for consumption has been examined in four pilot provinces in Black Sea Region. According to the research findings, it is stated that production and sales conditions of MCK affect the microbial flora of personnel hygiene and sanitation.

Ethics Committee Approval: Ethics committee approval is not required in this study.

Peer-review: Externally peer-reviewed.

Author Contributions: Concept- D.B.K.; DesignS.S., Y.C., C.E.; Materials- D.B.K., S.S., Y.C., C.E.; Data Collection and/or Processing- S.S., Y.C., C.E.; Literature Review- D.B.K., S.S.; Writing- D.B.K., S.S.; Critical Review- D.B.K

Conflict of Interest: No conflict of interest was declared by the authors.

Financial Disclosure: The authors declared that this study hasn't received no financial support.

\section{References}

Akpinar M, Petek A, Bagder Elmaci S, Halkman AK, Halkman B, Kocaker N, Kolcuoglu G, Omeroglu PY, Ozcelik F, Sagdas OE, Sancar BC, Yildirim G, Yilmaz A. Food Microbiology. Basak Printing and Promotion Services Limited Company 2019. Ankara, Turkey.

Andrews W. Manuals of Food Quality Control. 4. Microbial Analysis. FAO Consultant Food and Drug Administration Washington DC, USA. 1992.
Ardic M., Durmaz H. Determination of changes occurred in the microflora of cig kofte (raw meat balls) at different storage temperatures. İnternational Journal of Food Science Technology 2008; 43:805-809. https://doi.org/10.1111/j.13652621.2006.01519.x

Aslan S, Kara R, Akkaya L, Yaman H. Microbiological quality of raw meatballs sold in Afyonkarahisar, Academic Food 2012; 10(4): 2427. https://hdl.handle.net/20.500.12462/4669

Cerit I, Deniz G, Yuleci T, Ergun BE, Aygun MG, Karaduman I, Can C, Demirkol O. Determination of physico-chemical properties and monosodium glutamate content of meatless raw meatballs for sale in Sakarya province. Journal of Food Technologies Electronics. 2014; 9(3):10-17.

Delikanli B, Sonmez B, Ozdemir Y. Microbiological quality of meatless raw meatballs offered for consumption in the center of Bursa. Journal of Harran University Veterinary Faculty. 2014; 3(1):13-17.

https://dergipark.org.tr/en/pub/huvfd/issue/29577 /317289

Erol I. Food Hygiene and Microbiology. 1st Ed. Positive Printing. 2007. Ankara, Turkey.

Halkman K. Merck Food Microbiology Applications, 1st Ed., Basak Printing Limited Company, 2005, Ankara, Turkey.

Kardes, M. Microbiological quality of raw meatballs served for consumption in Siirt province. Master Thesis. Siirt University İnstitute of Science. Food Engineering Department. November 2017, Siirt, Turkey.

Kurt S, Ceylan HG. Fener M. Microbiological quality of raw meatballs for sale in Adiyaman, ADYUTAYAM 2019; 7(2):57-68.

Pamuk S, Gurler Z, Yildirim Y, Ertas N. The microbiological quality of ready to eat salads sold in Afyonkarahisar, Turkey. Kafkas Univ Vet Fak Derg. 2013; 19(6):1001-1006.

TSE. Tartar a la turca (Meatless), Turkish Standardization İnstitute, TS 13804, January 2018.

Vural A, Yesilmen S. A research on the microbiological quality of raw meatballs for sale in Diyarbakir. Turkish Journal of Microbial Society $2003 ; 33: 350-355$. 